\title{
Syndrome of Inappropriate Secretion of Antidiuretic Hormone (SIADH) and Gerhardt Syndrome Associated with Shy-Drager Syndrome
}

\author{
Hirohito Sone, Yukichi Okuda, Chieko Bannai, Seiji Suzuki, Takashi Yamaoka, \\ Yukari Asakura, Yasushi Kawakami, Masato Odawara, Teruhiko Matsushima, Koichi Kawai, \\ Toshihiro Yoshizawa*, Hidehiro Mizusawa* and Kamejiro Yamashita
}

This is the first report on a case of syndrome of inappropriate secretion of antidiuretic hormone (SIADH) associated with Gerhardt syndrome (paralysis of bilateral vocal cords). A 67-year-old Japanese man suffering from progressive autonomic failure was diagnosed as having Shy-Drager syndrome (SDS) with hyponatremia due to SIADH and severe sleep apnea caused by a bilateral recurrent nerve palsy. Water load test showed alteration in diuresis which was corrected by phenytoin. Arginine vasopressin secretion was not suppressed by plasma osmolality below 280 $\mathrm{mOsm} / \mathrm{kgH}_{2} \mathrm{O}$. Impairment of the afferent pathways of baroreceptors, or impairment of the osmoreceptors could be speculated as the etiological factor of the SIADH observed in this case. (Internal Medicine 33: 773-778, 1994)

Key words: arginine vasopressin (AVP), autonomic dysfunction, multiple system atrophy (MSA), phenytoin (diphenylhydantoin), pulse oxymeter

\section{Introduction}

Gerhardt syndrome is sometimes observed among patients with Multiple System Atrophy (MSA) including Shy-Drager syndrome (SDS). It is characterized by paralysis of both vocal cords and frequently sudden death (1-6). There are some reports of SIADH in patients with diabetic autonomic neuropathy $(7,8)$. However, SIADH with autonomic dysfunction in cases with MSA or SDS has not been reported. It was demonstrated that patients with MSA including SDS have an impaired arginine vasopressin (AVP) response when they are stimulated by upright posture despite the presence of severe orthostatic hypotension (9-12). Here, we report a case of SIADH and Gerhardt syndrome associated with SDS in a middle-aged man.

\section{Case Report}

A 67-year-old Japanese man was suffering from various autonomic symptoms from the age of 56. These consisted of constipation, urinary incontinence, disturbance of perspiration, impotence and severe orthostatic hypotension. During admission to the Tsukuba University Hospital, clinical and laboratory results showed moderate hyponatremia [serum sodium $(\mathrm{Na})$ level of $124 \mathrm{mEq} / \mathrm{l}]$, slight cerebellar ataxia and oily masked face. Based on various autonomic function tests (Table 1), he was diagnosed as having SDS. His marked snoring and sleep disturbance were investigated by polysomnography which exhibited severe sleep apnea for up to three minutes. Laryngoscopy revealed incomplete paralysis of bilateral vocal cords.

At the age of 64, a pacemaker was implanted due to sick sinus syndrome. The electrocardiogram did not show any signs of pacing failure. Conventional radiography and computed tomography (CT) scan of the chest did not show any active intrathoracic lesions. CT of the brain including hypothalamus and pituitary did not exhibit any abnormalities except slight diffuse cerebral atrophy and a few small lacunar infarctions, both of which are age-related alterations. Laboratory data (Table 2) showed a persistent and relatively high urine osmolality (approx. $500 \mathrm{mOsm} / \mathrm{kgH}_{2} \mathrm{O}$ ) despite a low plasma osmolality $\left(268 \mathrm{mOsm} / \mathrm{kgH}_{2} \mathrm{O}\right)$. The human atrial natriuretic peptide (hANP) level was twice the normal level. While the basal serum growth hormone $(\mathrm{GH})$ level was high, the $\mathrm{GH}$ response to either insulin $(0.1 \mathrm{U} / \mathrm{kg})$-induced hypoglycemia or growth hormone releasing hormone $(\mathrm{GRH})(1 \mu \mathrm{g} / \mathrm{kg})$ was markedly low (Table

From the Department of Endocrinology and Metabolism, *the Department of Neurology, the University of Tsukuba, Tsukuba

Received for publication January 27, 1994; Accepted for publication August 6, 1994

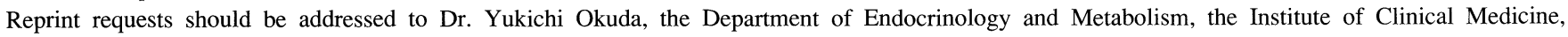
the University of Tsukuba, 1-1-1 Tennodai, Tsukuba 305 


\section{SonE et al}

Table 1. Results of Autonomic Function and Other Neurological Tests

\begin{tabular}{|c|c|}
\hline & $\begin{array}{l}\text { Aug. } 1992 \text { Blood pressure } 135 / 86 \rightarrow 95 / 66 \mathrm{mmHg} \text { (11 min.) } \\
\text { AVP 0.48 } \rightarrow 0.56 \mathrm{pg} / \mathrm{ml}\end{array}$ \\
\hline & Dec. 1993 Blood pressure $125 / 54 \rightarrow 88 / 55 \mathrm{mmHg}(10 \mathrm{~min}$. $)$ \\
\hline Hand cooling test: & Blood pressure $114 / 76 \rightarrow 107 / 71 \mathrm{mmHg}$ \\
\hline Sustained hand grip test: & Blood pressure $129 / 86 \rightarrow 128 / 83 \mathrm{mmHg}$ \\
\hline Perspiration test: & Almost no sweating in $38^{\circ} \mathrm{C}, 30 \%$ in humidity \\
\hline Pupil response tests (eye dropping of epinephrine, cocaine, tylamine): & $\begin{array}{l}\text { opping of epinephrine, cocaine, tylamine): } \\
\text { Normal response }\end{array}$ \\
\hline Shirmer, Gum test: & Normal response \\
\hline Uroflowmetry: & $\begin{array}{l}\text { Voiding volume (VV) } 51 \mathrm{ml} \\
\text { Residual volume (RV) } 160 \mathrm{ml} \\
\text { Maximal flow rate (MFR) } 4.2 \mathrm{ml} / \mathrm{sec} .\end{array}$ \\
\hline Cystmetry: & $\begin{array}{l}\text { First desire to void (FDV) } 175 \mathrm{ml} \\
\text { Maximal desire to void (MDV) } 206 \mathrm{ml} \\
\text { Maximal voiding pressure (MVP) } 125 \mathrm{cmH}_{2} \mathrm{O}\end{array}$ \\
\hline Nerve conducting velocity: & $\begin{array}{l}\text { Normal } \\
\text { Sensory nerve (median n., peroneal n.) } 56-63 \mathrm{~m} / \mathrm{sec} \text {. } \\
\text { Motor nerve (median n., sural n.) } 40-59 \mathrm{~m} / \mathrm{sec} \text {. }\end{array}$ \\
\hline
\end{tabular}

Table 2. Laboratory Data on the First (Aug. 1992) and Second (Dec. 1993) Admissions

\begin{tabular}{lrr}
\hline & Aug. 92, & Dec. 93 \\
\hline White blood cell count & 7,600, & $7,500 / \mu \mathrm{l}$ \\
Red blood cell count & 371, & $389 \times 10^{4} / \mu \mathrm{l}$ \\
Hemoglobin & 12.8, & $12.7 \mathrm{~g} / \mathrm{dl}$ \\
Platelet & 22.2, & $36.6 \times 10^{4} / \mu \mathrm{l}$ \\
Total protein & 6.5, & $6.0 \mathrm{~g} / \mathrm{dl}$ \\
Albumin & 4.3, & $3.4 \mathrm{~g} / \mathrm{dl}$ \\
$\mathrm{Na}$ & 124, & $138 \mathrm{mEq} / \mathrm{l}$ \\
$\mathrm{K}$ & 5.5, & $3.6 \mathrm{mEq} / \mathrm{l}$ \\
$\mathrm{Cl}$ & 89, & $97 \mathrm{mEq} / \mathrm{l}$ \\
Ca & 9.0, & $8.6 \mathrm{mg} / \mathrm{dl}$ \\
Blood urea nitrogen & 14.8, & $10.0 \mathrm{mg} / \mathrm{dl}$ \\
Creatinine & 0.9, & $0.6 \mathrm{mg} / \mathrm{dl}$ \\
Uric acid & 3.3, & $3.6 \mathrm{mg} / \mathrm{dl}$ \\
Total cholesterol & 133, & $157 \mathrm{mg} / \mathrm{dl}$ \\
Triglycerides & 51, & $80 \mathrm{mg} / \mathrm{dl}$ \\
Aspartate aminotransferase & 31, & $13 \mathrm{IU} / 1$ \\
Alanine aminotransferase & 49, & $11 \mathrm{IU} / \mathrm{l}$ \\
Lactate dehydrogenase & 433, & $401 \mathrm{IU} / \mathrm{l}$ \\
Alkaline phosphatase & 74, & $116 \mathrm{IU} / \mathrm{l}$ \\
$\gamma$-Glutamyltranspeptides & 58, & $31 \mathrm{IU} / \mathrm{l}$ \\
Cholinesterase & 145, & $186 \mathrm{IU} / \mathrm{l}$ \\
Total bilirubin & 0.8, & $0.3 \mathrm{mg} / \mathrm{dl}$ \\
Amylase & 146, & $66 \mathrm{IU} / \mathrm{l}$ \\
C-reactive protein & 0.1, & $0.4 \mathrm{mg} / \mathrm{dl}$ \\
Fasting plasma glucose & 96, & $109 \mathrm{mg} / \mathrm{dl}$ \\
Glycosylated hemoglobin & 6.5, & $6.6 \%$ \\
\hline
\end{tabular}

\begin{tabular}{|c|c|c|}
\hline & Aug. 92, & Dec. 93 \\
\hline \multicolumn{3}{|l|}{ Osmolality } \\
\hline (Plasma) & 268 & $277 \mathrm{mOsm} / \mathrm{kgH}_{2} \mathrm{O}$ \\
\hline (Urine) & 485 & $576 \mathrm{mOsm} / \mathrm{kgH}_{2} \mathrm{O}$ \\
\hline Adrenocorticotropic hormone & 43.8 & $41.7 \mathrm{pg} / \mathrm{ml}$ \\
\hline Thyroid stimulating hormone & 2.97 & $0.75 \mu \mathrm{IU} / \mathrm{l}$ \\
\hline Growth hormone & 2.8 & $0.4 \mathrm{ng} / \mathrm{ml}$ \\
\hline Follicle stimulating hormone & 12.1, & $32.9 \mathrm{mIU} / 1$ \\
\hline Luteinizing hormone & 6.5 & $9.7 \mathrm{mIU} / \mathrm{l}$ \\
\hline Prolactin & 9.5 , & $6.5 \mathrm{ng} / \mathrm{ml}$ \\
\hline Total triiodothyronine & 87 & $102 \mathrm{ng} / \mathrm{dl}$ \\
\hline Total thyroxine & 6.1 & $5.9 \mu \mathrm{g} / \mathrm{dl}$ \\
\hline Free thyroxine & 1.35 & $0.92 \mathrm{ng} / \mathrm{dl}$ \\
\hline Cortisol & 6.8 & $\mu \mathrm{g} / \mathrm{dl}$ \\
\hline 17-hydroxycorticosteroids & 4.4 & $\mathrm{mg} /$ day \\
\hline 17-ketosteroids & 3.7 & $\mathrm{mg} / \mathrm{day}$ \\
\hline Plasma renin activity & 0.6 , & $0.2 \mathrm{ng} / \mathrm{ml} / \mathrm{h}$ \\
\hline Aldosterone & 9.9 & $7.6 \mathrm{ng} / \mathrm{dl}$ \\
\hline Human atrial natriuretic peptide & $119-154$ & $\mathrm{pg} / \mathrm{ml}$ \\
\hline \multicolumn{3}{|l|}{$\begin{array}{l}\text { Catecholamine } \\
\text { (serum) }\end{array}$} \\
\hline Epinephrine & 0.05 & $\mathrm{ng} / \mathrm{ml}$ \\
\hline Norepinephrine & 0.16 & $\mathrm{ng} / \mathrm{ml}$ \\
\hline Dopamine & 0.20 & $\mathrm{ng} / \mathrm{ml}$ \\
\hline \multicolumn{3}{|l|}{ (urine) } \\
\hline Epinephrine & 12.0 & $\mu \mathrm{g} / \mathrm{day}$ \\
\hline Norepinephrine & 30.1 & $\mu \mathrm{g} / \mathrm{day}$ \\
\hline Dopamine & 430.0 & $\mu \mathrm{g} / \mathrm{day}$ \\
\hline
\end{tabular}

3). The GRH stimulation test was repeated once a day for five times, but the GH response did not improve. The response of plasma adrenocorticotropic hormone (ACTH) and serum cortisol to insulin-induced hypoglycemia was slightly low (Table 3 ). The basal serum cortisol and the daily excretion of 17hydroxycorticosteroids (17-OHCS) were within the normal range and no evidence of adrenal failure was detected.

The result of the oral water load $(20 \mathrm{ml} / \mathrm{kg})$ test (Fig. 1) revealed a reduced diuresis (excretion of only 47 percent of load volume after 4 hours). The intravenous administration of phenytoin $(500 \mathrm{mg})$, carried out simultaneously with oral water load test, markedly increased the diuresis (excretion of 117 
Table 3. Results of the Insulin Tolerance Test and the GRH Tests. The GRH Test was Repeated Once a Day for Five Times. Only the First and the Last Results are Shown

Insulin tolerance test $(0.1 \mathrm{U} / \mathrm{kg})$

\begin{tabular}{lrrrrrr}
\hline & 0 & 30 & 60 & 90 & 120 & $(\mathrm{~min})$. \\
\hline BS & 111 & \multicolumn{1}{c}{53} & 58 & 75 & 87 & $(\mathrm{mg} / \mathrm{dl})$ \\
GH & 3.3 & 1.6 & 2.5 & 3.3 & 2.8 & $(\mathrm{ng} / \mathrm{ml})$ \\
ACTH & 27.8 & 20.6 & 21.7 & 33.1 & 17.6 & $(\mathrm{pg} / \mathrm{ml})$ \\
Cortisol & 10.3 & 9.1 & 13.9 & 13.2 & 10.2 & $(\mu \mathrm{g} / \mathrm{ml})$ \\
\hline
\end{tabular}

GRH tests $(1 \mu \mathrm{g} / \mathrm{kg}$ i.v. $)$

\begin{tabular}{lcccccc}
\hline & 0 & 30 & 60 & 90 & 120 & $(\mathrm{~min})$. \\
\hline GH (1) & 2.4 & 3.8 & 1.1 & 0.5 & 0.4 & $(\mathrm{ng} / \mathrm{ml})$ \\
GH (5) & 2.1 & 5.0 & 1.4 & 0.5 & 0.3 & $(\mathrm{ng} / \mathrm{ml})$ \\
\hline
\end{tabular}

GH (1): the first test, GH (5): the fifth test.

percent of load volume after 4 hours). Plasma AVP levels decreased only slightly during the water load. On the other hand, AVP response (from 0.48 to $0.56 \mathrm{pg} / \mathrm{ml}$ ) to the head-up inclination (table tilting of 60 degrees over the horizontal) was very low despite the occurrence of severe orthostatic hypotension (from 135/86 to 95/66 mmHg) (Table 1). Water restriction $(750 \mathrm{ml} /$ day) ameliorated the serum $\mathrm{Na}$ concentration to within the normal range (135-140 $\mathrm{mEq} / \mathrm{l})$. However, oral administration of phenytoin did not affect the serum Na levels.

A tracheotomy was indicated due to the risk of sudden death observed in Gerhardt syndrome; it was not performed however as the patient did not consent to it. Careful follow-up of his sleep apnea syndrome was carried out at home using a pulse oxymeter. The oxygen saturation was controlled during sleeping time; the patient was awoken when the oxygen saturation was lowered to $85 \%$ or less. Once discharged from hospital, he was observed in the outpatient clinic and he was doing well for almost a whole year with pulse oxymeter checking three or four times a night. However, as he could not sleep well due to the pulse oxymeter alarms, he chose to stop using it without any consultation with us.

A month after he stopped using the pulse oxymeter, he was apneic at midnight and he was referred to our hospital in August 1993. Cardiopulmonary resuscitation and tracheotomy were performed at this time. He received mechanical ventilation for about two weeks. During the convalescent period, there was no particular alteration in the laboratory data (Table 2), except in the serum $\mathrm{Na}$ level, compared to that of the former admission data. Oral water load test $(20 \mathrm{ml} / \mathrm{kg}$ ) was again carried out (Fig. 1) and revealed a slight aggravation of urine excretion (excretion of only 30 percent of load volume after 4 hours). Orthostatic hypotension was also aggravated requiring intravenous and oral administration of dopaminergic hypertensors. However, the serum $\mathrm{Na}$ level remained normal under the same water restriction.

\section{Discussion}

On the first admission, persistent hyponatremia and low plasma osmolality were seen, despite a higher urine osmolality as compared to that of the plasma. Psycogenic polydipsia and pseudohyponatremia was ruled out by the anamnesis. The etiology of the SIADH was investigated. Etiological factors like intrathoracic lesions, ectopic secretion by malignant tumor and drug-induced SIADH were not compatible with this case. Results of the phenytoin test suggest that inappropriate hypersecretion of AVP originated from the pituitary, rather than from an ectopic malignant lesion $(13,14)$.

The plasma hANP level was twice that of the normal concentration in this case. Plasma hANP levels of patients with SIADH increase to 6-fold the normal levels, though there are many individual variations (15). This is considered to occur in response to water retention secondarily induced by SIADH, because no significant correlation between plasma AVP and hANP levels is found in SIADH patients (16). Further, there is no report showing that hypersecretion of hANP is the primary cause of hyponatremia in patients with SIADH. In the current case, the elevation of hANP levels was considered to be caused by his VVI-type pacemaker which was reported to increase the hANP levels to twice that of the normal levels (17). Moreover, implanted pacemakers do not induce AVP secretion and do not cause SIADH. Thus, the cause of the SIADH in this case was not related to the hANP or the pacemaker.

To date, only a single case of SIADH associated with SDS (but without paralysis of vocal cords) has been reported (18). In their case, atrophy of the hypothalamus detected by magnetic resonance imaging (MRI) was considered as the etiological factor of the SIADH. These lesions were not detected by CT scan in the present case. MRI could not be performed because of his pacemaker.

The relationship between plasma osmolality and the AVP level in the present case (Fig. 2) can be explained by a hypersecretion of AVP in response to a plasma osmolality below 280 $\mathrm{mOsm} / \mathrm{kgH}_{2} \mathrm{O}$, though the AVP response to a higher plasma osmolality was almost normal. On the other hand, the AVP response to orthostatic postural stimulation is reported to be low in patients with MSA including SDS as was seen in this case also, though it was found to be high in patients suffering from other causes of orthostatic hypotension (9-12). So far, only one case of diabetes insipidus with SDS has been reported (19). Cluster breathing was associated with that case, suggesting damage of the pontomedullary respiratory center. It is suggested that the poor AVP response to orthostatic postural stimulation in SDS patients is primarily due to integrated lesions of the afferent baroreflex pathways (12).

In the present case, the real etiology of the SIADH is not clear. The afferent pathways of baroreceptors of the left atrium and the carotid sinus that reach the hypothalamus through the vagus and nucleus tractus solitarius are known to be inhibitory tracts (20). Hence, it can be speculated that both SIADH and bilateral recurrent nerve palsy could simultaneously occur by impairment of these tracts. Another possible explanation for the 
SONE et al
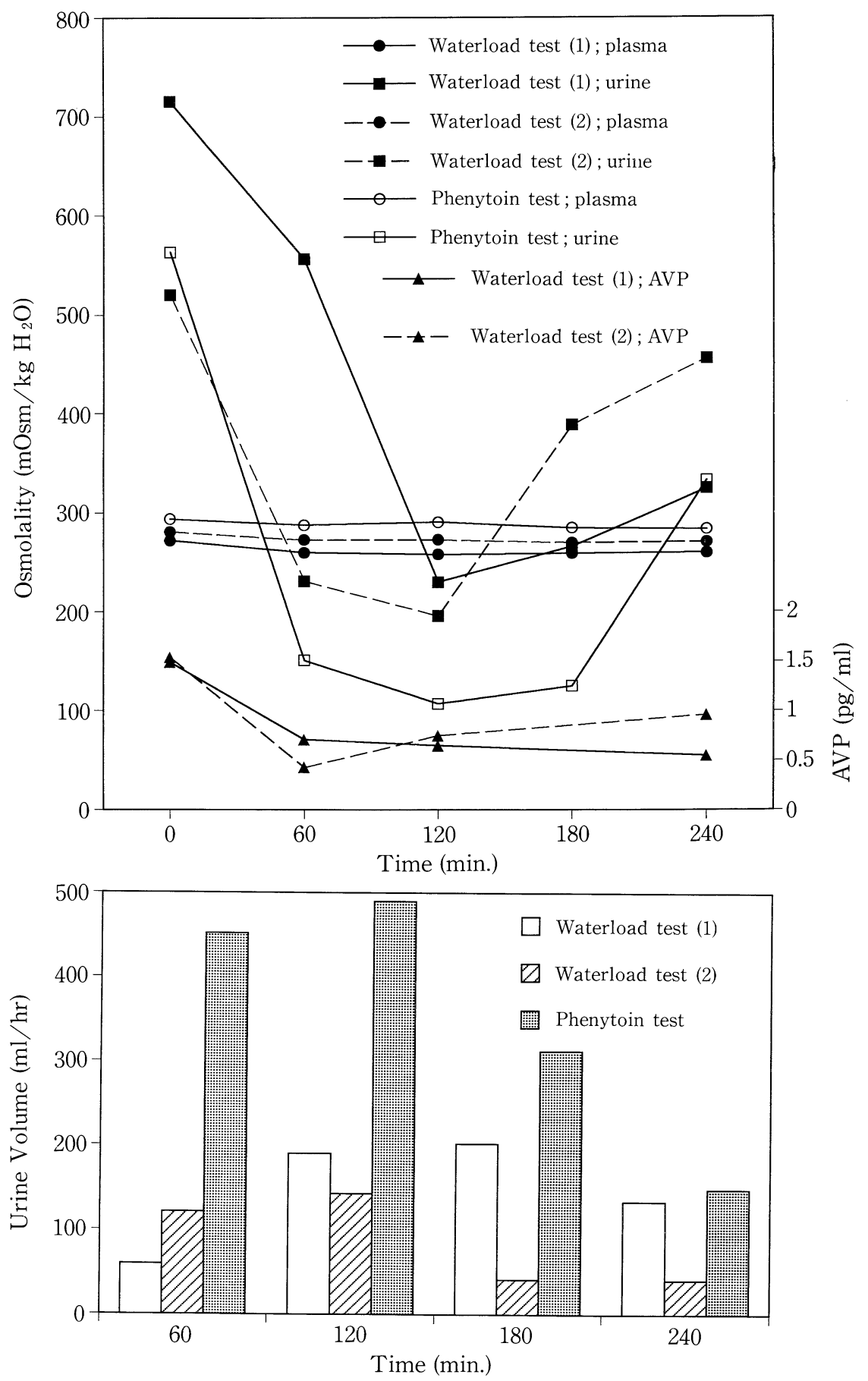

Fig. 1. Results of the oral water load tests (20 ml/kg) carried out on the first (1) (Aug. 1992) and the second (2) (Dec. 1993) admission and the oral water load test with intravenous phenytoin $(500 \mathrm{mg})$ administration carried out on the first admission.

low AVP response to head-up inclination and exaggerated secretion despite low plasma osmolality is a dysfunction of the osmoreceptors of low plasma osmolality of the hypothalamus that was not detected by the CT scan. Hypothalamic lesion in this case could explain the concurrent existence of hypersecretion of basal GH and the low GH response to the stimulation tests. These are sometimes observed among patients with SDS or Parkinsonism, which is considered to be caused by an abnormality of the tuberoinfundibular dopaminergic system of the hypothalamus (20-22).

AVP is a hormone that controls the peripheral circulation through its antidiuretic and pressor effects. However, recent 
SIADH and Gerhardt Syndrome with SDS

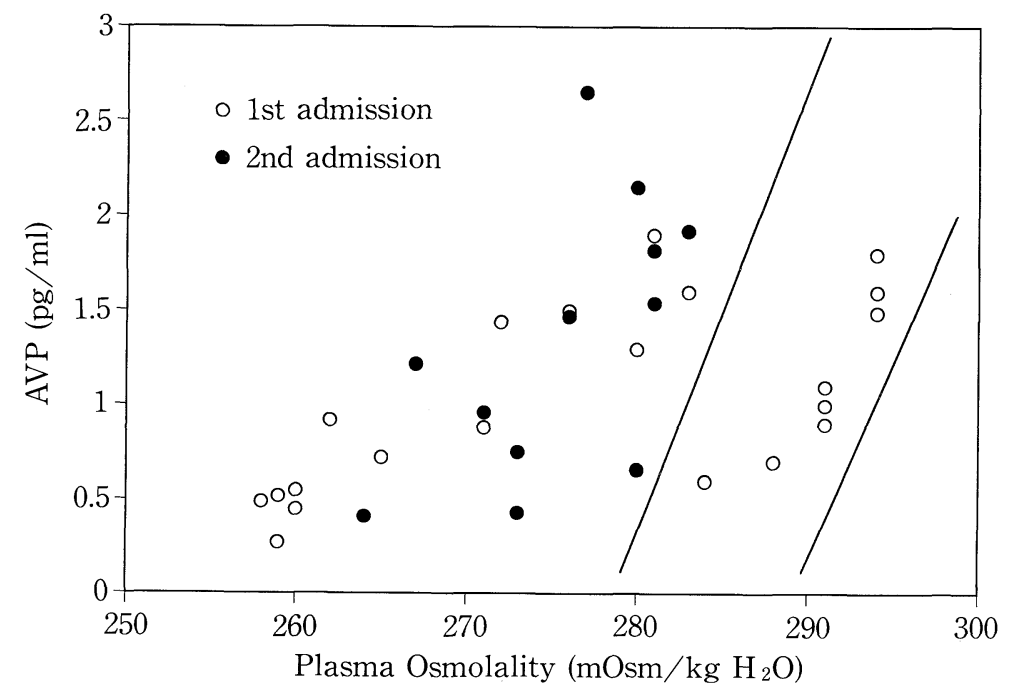

Fig. 2. The relationship between plasma osmolality and AVP level on each admission. The area between the two lines indicates the normal range of AVP secretion.

investigations $(23,24)$ revealed that AVP exerts dual and direct effects on the central nerve system acting as a neurotransmitter for inhibiting or accelerating the sympathetic nerve activity. The complex interaction between AVP and the autonomic system is presently under elucidation.

The etiology of Gerhardt syndrome associated with SDS or MSA is still obscure. Although there is one report stating that treatment with L-dopa produced a demonstrable improvement (2), this was not effective in the present case; tracheotomy is considered the only reliable therapeutic approach. On the first admission, we used a pulse oxymeter to prevent sudden death during periods of sleep apnea by making him wake up. It seems to be an effective method and it is worthy to attempt if the patients' understanding and cooperation can be obtained.

In summary, this is the first report on a case of SIADH and Gerhardt syndrome associated with SDS. The findings suggest that SDS may be a causal factor of SIADH.

Acknowledgment: The authors thank Dr. K. Ishii, Dr. M. Adachi and Dr. A. Shinagawa of the Tsukuba University Hospital for their assistance in autonomic function tests.

\section{References}

1) Bannister R, Gibson W, Michaels L, Oppenheimer DR. Laryngeal abductor paralysis in multiple system atrophy. Brain 104: 351, 1981.

2) Gilmartin JJ, Wright AJ, Cartlidge NEF, Gibson GJ. Upper airway obstruction complicating the Shy-Drager syndrome. Thorax 39: 313 , 1984.

3) Martinovits G, Leventon G, Goldhammer Y, Sadeh M. Vocal cord paralysis as a presenting sign in the Shy-Drager syndrome. J Laryngol Otol 102: 280, 1988

4) Munschauer FE, Loh L, Bannister R, Newsom-Davis J. Abnormal respiration and sudden death during sleep in multiple system atrophy with autonomic failure. Neurology 40: 677, 1990.

5) Yasuda T, Senda Y, Koike Y, Hakusui S, Takahashi A. Bilateral abductor vocal cord paralysis (Gerhardt syndrome) in the Shy-Drager syndrome. Clin Neurol 29: 1232, 1989 (in Japanese with English abstract).
6) Isozaki E, Miyamoto $\mathrm{K}$, Osanai R, Hayashida $\mathrm{T}$, Tanabe H. Clinical studies of 23 patients with multiple system atrophy presenting with vocal cord paralysis. Clin Neurol 31: 249, 1991 (in Japanese with English abstract).

7) Sato K, Kimura T, Shoji M, Inoue M, et al. A case of syndrome of inappropriate secretion of antidiuretic hormone associated with diabetes mellitus. Endocrinol Jpn 38: 331, 1991.

8) Yaginuma K, Hashimoto S, Mizuno K, Ogawa S, Haruyama K, Fukuchi $\mathrm{S}$. A case of diabetes mellitus with the idiopathic syndrome of inappropriate secretion of antidiuretic hormone. Folia Endocrinol Jpn 59: 248, 1983 (in Japanese with English abstract).

9) Puritz R, Lightman SL, Wilcox CS, Forsling M, Bannister R. Blood pressure and vasopressin in progressive autonomic failure. Brain 106: 503, 1983.

10) Williams TDM, Lightman SL, Bannister R. Vasopressin secretion in progressive autonomic failure: Evidence for defective afferent cardiovascular pathways. J Neurol Neurosurg Psychiatry 48: 225, 1985.

11) Senda Y, Koike Y, Oiso Y, Matsuoka Y, Takahashi A.Plasma vasopressin response to orthostasis and hypertonic saline infusion in progressive autonomic failure. Clin Neurol 28: 1282, 1988 (in Japanese with English abstract).

12) Kaufmann H, Oribe E, Miller M, Knott M, Wiltshire-Clement M, Yahr MD. Hypotension-induced vasopressin release distinguishes between pure autonomic failure and multiple system atrophy with autonomic failure. Neurology 42: 590, 1992.

13) Fichman MP, Kleeman CR, Bethune JE. Inhibition of antidiuretic hormone secretion by diphenylhydantoin. Arch Neurol 22: 45, 1970.

14) Guzek JW, Russel JT, Thorn NA. Inhibition of diphenylhydantoin of vasopressin release from isolated rat neurohypophyses. Acta Phamacol et Toxicol 34: 1, 1974

15) Manoogian C, Pandian M, Ehrlich L, Fisher D, Horton R. Plasma atrial natriuretic hormone levels in patients with the syndrome of inappropriate antidiuretic hormone secretion. J Clin Endocrinol Metab 67: 571, 1988.

16) Kamoi K, Ebe T, Kobayashi O, et al. Atrial natriuretic peptide in patients with the syndrome of inappropriate antidiuretic hormone secretion and with diabetic insipidus. J Clin Endocrinol Metab 70: 1385, 1990.

17) Taniguchi $T$, Shimizu $T$, Masuda $Y$, Yamamoto H, Yagi S. Effect of tricuspid regurgitation on secretion of atrial natriuretic peptide in patients with permanent pacemaker. Jpn J Cardiac Pacing Electrophysiol 8: 312, 1992 (in Japanese with English abstract).

18) Nagumo K, Kita K, Kitano K, Simoe Y, Furumoto H. Shy-Drager 


\section{SonE et al}

syndrome and the syndrome of inappropriate secretion of antidiuretic hormone. Clin Neurol 32: 177, 1992 (in Japanese with English abstract).

19) Lockwood AH. Shy-Drager syndrome with abnormal respirations and antidiuretic hormone release. Arch Neurol 33: 292, 1976.

20) Konagaya $Y$, Konagaya $M$, Takayanagi $T$. Tuberoinfundibular dopaminergic neuron function in Shy-Drager syndrome. Clin Neurol 23: 861, 1983 (in Japanese with English abstract).

21) Konagaya $K$, Konagaya $M$, Takayanagi $T$. Anterior pituitary dopamine receptor function in Shy-Drager syndrome. Clin Neurol 24: 920, 1984 (in Japanese with English abstract).
22) Konagaya $\mathrm{Y}$, Konagaya M, Takayanagi T. Tuberoinfundibular dopaminergic system and anterior pituitary dopamin receptor in ShyDrager syndrome. J Neurol Sci 67: 93, 1985.

23) Suzuki S, Imaizumi T. Vasopressin in central cardiovascular regulation. Saishin Igaku 46: 90, 1991 (in Japanese with English abstract).

24) Ishikawa $S$, Saito $T$. Vasopressin gene and manifestation of vasopressin receptor and its physiological reaction. in: Circulatory Regulation Peptides and Its Related Diseases. Yazaki Y, Yodo Company, Tokyo, 1992, p.41 (in Japanese). 